\title{
FOLKLORISTIC COMMENTARY
}

The publication of two major manuscript collections of Karok folk narratives in a single volume is an important milestone in the study of California Indian cultures. For students of native American folktales, it will prove to be an indispensable source. In 1935, well before Gifford had even made his collection, Anna Gayton, in her remarkably comprehensive overview of the distribution patterns of California Indian folktales, bothered to complain that Kroeber's collection of Karok myths was available only via the footnotes in Du Bois and Demetracopoulou's 1931 monograph on Wintu myths (Gayton 1935:584, n. 7). In effect, it was essentially only graduate students at Berkeley who had access to these valuable primary materials. Permelia Catharine Holt, for example, in her impressive 1942 doctoral dissertation devoted to finding analogues for Shasta folk narratives made extensive use of both the Kroeber and Gifford Karok manuscripts. But aside from these very occasional instances, specialists in American Indian folklore have not been able to take proper advantage of the Karok field data gathered by Kroeber in the first decade and Gifford in the fourth decade of the twentieth century.

Despite the overall title Karok Myths, the materials fall mostly under the generic rubric of folktales. In addition, Kroeber's collection ends with some random ethnographic gleanings, not in narrative form at all, while Gifford's collection concludes with a set of formulas or charms intended for medicinal, magical, or ritual purposes. Narratives functioning as charms in native American life have not been collected as often as they might have been (cf. Kilpatrick and Kilpatrick 1965, 1967; Holt 1942:152), and this makes Gifford's 
Karok compilation all the more valuable. For example, we can now compare the flood story used as an apotropaic formula when crossing a river in a boat (V.29) with more conventional nonritual narrative versions $(\mathrm{F} 6, \mathrm{I} .3)$.

One indication of the authenticity of the narratives in this combined collection is the absence of European tales. Not that there is anything wrong with reporting native American retellings of European tale types; quite the contrary, inasmuch as such retellings can often provide valuable indices of acculturation. But in this body of narratives there is only one apparent non-native tale (II.52). In this tale, collected in 1940, a turtle stations another turtle at the finish line of a race which enables him to beat a squirrel. This is unquestionably a version of Aarne-Thompson tale type 1074, Race Won by Deception: Relative Helpers. Decades ago, Stith Thompson listed nearly a dozen American Indian retellings of this tale in the published version of his doctoral dissertation (1919:449). He considered the tale to be of European provenience, whereas the thirty-nine versions from Africa listed in the most recent edition of the tale type index make it equally likely that it may be an African tale type. In any case, with the exception of this single tale, the present compilation of Karok tales includes only traditional American Indian tale types. The reader should keep in mind that these narratives are for the most part standard California Indian narratives. Large numbers of cognate tales can easily be found among many California Indian tribal groups, not to mention American Indian groups in the Northwest Coast, Plateau, and Basin culture areas. Thus while readers familiar with classical mythology and Indo-European folklore may be unable to resist seeing what they construe as parallels with "Ariadne and Theseus" or "Hansel and Gretel," they should make a concerted effort to understand Karok narratives in their own terms.

Nearly every single narrative in this book has its own distinct identity and if time and space permitted, one could show the wide geographical range of each tale's distribution in native North America. Editor Grace Buzaljko's valuable index of parallel plot elements in representative Karok and Yurok narrative collections (included as an appendix to this volume) is a step in the right direction, although of course it is no substitute for a full-scale California Indian motif or tale type index. The vast majority of the plot elements are in fact standard motifs, and a researcher familiar with 
Thompson's six-volume Motif-Index of Folk Literature (1955-58) may wish to consult that source to find additional parallels to a given element.

For example, the story of Coyote and Blowfly (I1.21) or Coyote and Fly (II.22) tells how Blowfly obtains meat by entering a deer's rectum and cutting off fat. Coyote, inevitably greedy, tries in his turn to cut off too much and he gets trapped in the deer's anus. This is almost certainly a version of a standard American Indian tale (Motif J2425, The bungling host). Franz Boas discussed this tale type in some detail (1916:694-702), as did Stith Thompson (1929:301, n. 103). Faber's more recent study (1970) was based upon well over two hundred versions of this popular and widespread tale. It turns out that the presence of Fly or Blowfly as host is quite unusual, but the anal source of food is not. Typically, the host cuts fat out of his own anus (or nose, a common anal symbolic substitute), but the dupe fails in his attempt to imitate him (cf. Boas 1916:697-698; Faber 1970:72, 90-93, 105-106). The final riotous scene of Coyote captivus being dragged about by Deer while protruding from Deer's anus certainly attests to the importance of this area of the body in Karok thought. This same theme is also evident in the Karok tales (II.15, II.17) in which Coyote plugs up his own rectum with pitch so that he can retain the numerous grasshoppers he eats. Noteworthy is the fact that in both Karok versions of this tale, found also among the Shasta, Hupa, Wintu, and Takelma (Holt 1942:127-129), the narrative begins with Coyote's searching for dentalia or the Karok equivalent of wealth. This strongly suggests the possible symbolic equation of wealth and feces-plugging up the anus to retain or "save" the grasshoppers orally incorporated-an equation which is also common among the Yurok and Northwest Coast peoples (cf. my commentary in Kroeber 1976:xxxv).

Among the more familiar narratives in the collection are versions of the theft of fire $(A 7, F 11 ; 11.7,11.43)$. The relevant motif is Motif A 1415.2, Theft of fire by animals. The theft of fire is a very popular American Indian narrative (cf. Boas 1916:660-663; Thompson 1929:289, n. 63; Gayton and Newman 1940:60-63; Holt 1942: 27-31). Gayton in her 1935 survey essay suggested that the relayrunners form of the narrative constituted a distinct northern California and Basin subtype (1935:590). The consistent occurrence in Karok versions of the frog as final runner in the relay is quite rare 
elsewhere, although it is also reported in Wintu and Shasta accounts (Holt 1942:30).

Another widespread American Indian tale is the story of the Pleiades (cf. Motif A773, Origin of the Pleiades). The narrative is common enough in California (Gayton and Newman 1940:65-66); the association with dancing is not, although dancing is reported elsewhere. Wycoco in her unpublished tale type index for native North America has isolated one subtype which she described as "A band of dancing children are translated to the sky as the Pleiades as a punishment for disobedience"' (Wycoco 1951:43-44), which is found among groups as diverse as the Eskimo, the Paiute, and the Iroquois. In one of the Karok texts (A9, but not II.51) we find once again the already noted preoccupation with the anus.

Other recognizable American Indian tale types in the collection include the Loon Woman (A8, I.9), a classic narrative of sister-brother incest, studied by Dorothy Demetracopoulou (Lee); and Trickster marries his daughter (II.44, II.45), an equally classic tale of fatherdaughter incest studied by Henrietta Schmerler. For those readers who may not fully appreciate why folklorists are so pleased to have access to additional versions of standard tale types already known to them, let me briefly discuss two separate narratives contained in the present Karok corpus: the stolen brother and the bird-nest seeker.

In the story of Crooked Nose and the Stolen Brother (B3), the protagonist's younger brother violates an interdiction not to cook meat with fat, an act that summons an unidentified mysterious being which proceeds to carry off the younger brother. Crooked Nose forces a bird to reveal the whereabouts of the missing brother. He then organizes a party of animals who ascend to the sky world. Mouse is instructed to make holes in the enemies' boats (to prevent eventual pursuit). Crooked Nose disguises himself as the old woman who fells trees and who ferries people across the river. He passes a test consisting of swallowing hot stones without blinking his eyes. Then he proceeds to where his younger brother is hanging near death and removes him, leaving a mouse in his place. He crosses the river while the pursuers are unable to follow because their boats (with the holes in them) sink. In one of Gifford's formula stories, reportedly used both to encourage rapid tobacco growth and to hasten tree felling by fire (V.33), we find another version of this tale. A younger brother eats the fat meat of a deer. A mysterious "nice 
little thing" comes and licks up the spit the younger brother put on his hand, a detail also found in the earlier Karok version. The thing begins to eat more and more until finally it devours the entire supply of dried meat. The older brother fails repeatedly to reply to his younger brother's inquiries, and the younger brother disappears. A bird, trapped by the older brother, reveals the younger brother's location. Enroute, the older brother encounters "Day-moon," who advises him to kill the old woman who sits by the fire that is burning down the tree, and don her clothing and cap. (An older Karok version also has the sun-informant motif, according to Holt 1942:80.) He does so, taking moles and mice with him to scuttle the enemy boats. He rescues his brother in the nick of time and the pursuers fail to catch them because of the holes in their boats, which is a standard motif (Motif K636, Holes bored in enemies' boats prevent pursuit) reported in Iceland and Indonesia as well as aboriginal North America.

The narrative of the retrieval of a stolen brother is extremely popular in California (Holt 1942:76-83) as well as in the Northwest Pacific Coast. The reason why it is of particular interest to students of North American Indian folklore stems from a fascinating debate about the possible meanings of the tale. In 1958-1959, Melville Jacobs published tales he had collected in 1929 and 1930 in Oregon from Mrs. Victoria Howard, one of the last speakers of Clackamas Chinook. One of these tales "Seal and her younger brother dwelt there," is a fragment of the stolen brother tale type. Mrs. Howard herself indicated her tale's fragmentary nature by her concluding words "Now I remember only that far" (1959:340-341). In the narrative fragment, Seal's daughter tries to warn her mother that her uncle (Seal's brother) has a peculiar new wife. Specifically, the new wife urinates like a male. Mother Seal ignores her daughter's warnings and is shocked next morning to find that the uncle's head has been cut off by his "wife." Jacobs in his later interpretation of the tale (1960:238-242) suggests that the sexually aberrant "wife" might be a homosexual. However, he can offer no explanation as to why the murderer committed the crime. Dell Hymes, dissatisfied with Jacobs' interpretation, offered an extensive reanalysis of the narrative and suggested that the "wife" was not a murderous transvestite or homosexual but rather a trickster (1968:184). More recently, the tale has been interpreted again by Jarold Ramsey in an article in 
PMLA. Ramsey correctly observed that the Clackamas Chinook fragment was in fact part of a longer narrative and cited a 1903 Coos text, "The Revenge Against the Sky People" (Ramsey 1977:1213). The narrative includes the ferry woman, the boring of holes in the canoes, and other comparable details. In the Coos narrative, it is an older brother who is mysteriously killed by a stranger and who is rescued by a younger brother. It is clear that the killing of the ferry woman and donning of her skin represents a crafty strategem rather than an overt act of homosexuality as Jacobs originally argued. However, even in the Coos text, one finds no real motivation given for the original act of murder by the stranger from the sky world. In this context, it is interesting that in the present Karok versions, we do find motivation, namely the younger brother's violation of an eating interdiction. According to Holt's detailed comparative consideration of the various traits of this tale type, the roast meat or fat taboo is found only among the Wintu, the Hupa, and the Karok (Holt 1942:82). It would be inappropriate to extend the discussion of this tale here. Those readers genuinely interested in the range of interpretations of native American oral literature would do well to read the essays by Jacobs, Hymes, and Ramsey for themselves. The point is simply that the availability of two Karok versions of this fascinating tale type will surely add to our appreciation of the tribal variations and creativity within the framework of a given basic plot.

For similar reasons, we must be grateful for so many Karok versions of the narrative wherein an old man persuades a young man (son, son-in-law) to climb up to a bird's nest to obtain the fledglings, after which the old man removes the poles or ladder, thereby stranding the youth (A10, C2, D3; I.1, III.37, III.38). This narrative is very likely related to either motif $\mathrm{K}$ 1616.1, Marooned egg-gatherer, or B31.1, Roc, a giant bird which carries off men in its claws. The old man's motivation is typically that he has amorous designs on the young man's wife. In some versions, while the son is engaged in climbing a tree, the old man magically causes the tree to stretch. Here we certainly have an instance of motif K1113, Abandonment on stretching tree, and motif S11.2, Jealous father sends son to upper world on stretching tree (cf. Thompson 1929:332, n. 199; Gayton 1935:585, n. 15; Holt 1942:45-47, 50). In this battle between old man and young man, or in some cases, father and son, the possible phallic significance of a stretching tree is evident enough. It is the father, not 
the son, who controls the power of the tree. Ironically, in most versions the son-hero is forced to kill the bird-analogs to himself, namely, the fledglings. Placing the hero in a bird's nest is an attempt, perhaps, to infantilize him, but the hero is finally successful in overcoming his older male adversary.

What makes this narrative of special interest is that the very same tale is found in South America and what is more, Lévi-Strauss has chosen it as the basic or key myth of his elaborate and ambitious four-volume work devoted to mythology. He begins his major mythological opus stating, "I shall take as my starting point one myth, originating from one community" and the myth he selects from the Bororo Indians of central Brazil is none other than what he calls "The Bird-Nester's Aria" (1969:35-37). In this narrative, a father discovers that his son has raped his mother. Furious, the father forces the boy to submit to a series of tests, one of which is to capture macaws nesting on top of a cliff. He provides a long pole by means of which the boy ascends. The father then removes the pole thereby stranding his son. At the end of Lévi-Strauss's key myth, the son takes revenge on his father by donning false deer antlers and impaling him on the horns. It is tempting to speculate that the son who originally rose on the erection of his father's pole, that is, served as the victim of phallic aggression (while being punished for his own phallic aggression against his mother) succeeds in turning the tables by penetrating his father in the end! Lévi-Strauss in later volumes discusses additional South American Indian versions (e.g., 1973:334-358), and in the fourth and final volume of his series he considers a number of North American Indian versions of the tale (1971:450-451 , 469-478). No doubt he would have appreciated having had access to the Karok versions now being published.

So these two collections of Karok narratives by Kroeber and Gifford will happily be henceforth available to serious students of American Indian folklore. The texts are not only precious native documents in and of themselves, but they will become part of the mainstream of current scholarship dedicated to the exploration of the meaning of Native American oral literature. Future investigations of individual American Indian tale types will be able to draw freely upon the rich store of Karok tradition. For this reason, I am delighted that my initial suggestion that the two manuscripts be combined has, thanks largely to Grace Buzaljko's extraordinary 
editorial skills, resulted in a single and singular volume truly worthy of standing next to Kroeber's Yurok Myths on library shelves. Despite the lack of storytelling performance contexts, the great variety of informants, the different personalities of the two ethnographers, and the forty-year timespan between the two collecting periods, something of the Karok voice survives translation to speak forever not only to Karok and other California Indian descendants but to all of us who take pleasure in the art of traditional narrative.

Alan Dundes

Literature Cited

Aame, Antti, and Stith Thompson

1961. The Types of the Folktale. Second Revision. Helsinki: Academia Scientiarum Fennica.

Boas, Franz

1916. Tsimshian Mythology. Annual Report of the Bureau of American Ethnology, No. 31. Washington, D.C.: Government Printing Office.

Demetracopoulou, Dorothy

1933. The Loon Woman Myth. Journal of American Folklore 46:101-128.

Du Bois, Cora, and Dorothy Demetracopoulou 1931.

Wintu Myths. UC-PAAE 28:(no.5):279-403.

Faber, Mac Jean 1970.

The Tale of the Bungling Host: A Historic-Geographic Analysis. Unpublished M.A. thesis in anthropology, San Francisco State University.

Gayton, A. H. 1935.

Areal Affiliations of California Folktales. American Anthropologist 37:582-599.

Gayton, A. H., and Stanley S. Newman 1940. Yokuts and Western Mono Myths. UC-AR 5:(no. 1):1-109.

Holt, Permelia Catharine 1942.

The Relations of Shasta Folk Lore. Unpublished doctoral disHymes, Dell $\mathrm{H}$. sertation in anthropology, University of California, Berkeley.

1968.

The "Wife" Who "Goes Out" Like a Man: Reinterpretation of a Clackamas Chinook Myth. Social Science Information 7:173-199. Reprinted in Structural Analysis of Oral Tradition, ed. Pierre Maranda and Elli Köngäs Maranda. University of Pennsylvania Press, Philadelphia, 1971. Pp. 49-80. 
Jacobs, Melville

1959. Clackamas Chinook Texts, Part 2. Indiana University Research Center in Anthropology, Folklore, and Linguistics, Publication 11. Bloomington.

1960. The People Are Coming Soon: Analyses of Clackamas Chinook Myths and Tales. Seattle: University of Washington Press.

Kilpatrick, Jack F., and Anna G. Kilpatrick

1965. Walk in Your Soul: Love Incantations of the Oklahoma Cherokees. Dallas: Southern Methodist University Press.

1967. Run Toward the Nightland: Magic of the Oklahoma Cherokees. Dallas: Southern Methodist University Press.

Kroeber, A. L.

1976.

Yurok Myths. Berkeley and Los Angeles: University of California Press.

Lévi-Strauss, Claude

1969.

The Raw and the Cooked. New York: Harper \& Row. Originally published as Le Cru et le Cuit, Plon, Paris, 1964.

1971. L'Homme Nu. Paris, Plon.

1973. From Honey to Ashes. New York: Harper \& Row. Originally published as Du Miel aux Cendres, Plon, Paris, 1966.

Ramsey, Jarold W.

1977.

The Wife Who Goes Out Like a Man, Comes Back as a Hero: The Art of Two Oregon Indian Narratives. PMLA 92:9-17.

Schmerler, Henrietta

1931. Trickster Marries His Daughter. Journal of American Folklore 44:196-207.

Thompson, Stith

1919.

European Tales Among the North American Indians: A Study in the Migration of Folk-Tales. Colorado College Publication, Language Series, Vol. 11, No. 34, pp. 319-471.

1929. Tales of the North American Indians. Cambridge: Harvard University Press. Reprinted by Indiana University Press. Bloomington, 1966.

1955-58. Motif-Index of Folk Literature. 6 vols. Bloomington: Indiana University Press.

Wycoco, Remedios S.

1951 .

The Types of North-American Indian Tales. Unpublished doctoral dissertation in English, Indiana University, Bloomington. 
